UDC: 811.161.1(075)(049.32)

\title{
Н. Л. ФЕДОТОВА. (2013). МЕТОДИКА ПРЕПОДАВАНИЯ РУССКОГО ЯЗЫКА КАК ИНОСТРАННОГО. ПРАКТИЧЕСКИЙ КУРС. ЗАДАЧНИК К ПРАКТИЧЕСКОМУ КУРСУ. САНКТ-ПЕТЕРБУРГ: ЗЛАТОУСТ.
}

Уџбенички комплет Методика преподавания русского языка как иностранного. Практический курс. Задачник к практическому курсу остварење је доктора педагошких наука Нине Леонидовне Федотове, ауторке преко 70 научних радова и једног од познатијих имена у методици наставе руског језика као страног са Државног универзитета у Санкт Петербургу. Поља њеног интересовања примарно су усмерена ка методици наставе руског језика као страног, премда треба истаћи још и подручја фонетских истраживања, тестирања, као и иновативних метода у настави. Радећи на курсевима руског језика у Кини, Аустрији и Немачкој, затим изводећи наставу на матичном универзитету, Нина Федотова стекла је велико искуство из области методике наставе, што је, осим радова, резултирало и учешћем у изради неколиких колективних монографија и више од пет приручника из поменутих области.

Комплет који се налази пред нама намењен је пре свега студентима факултета филолошког и педагошког усмерења, затим студентима мастер студија лингвистичких и лингводидактичких модула, докторандима и наставницима руског језика. Као такав он може да послужи као допуна већ постојећим уџбеницима методике наставе руског језика као страног, а састоји се из три дела: практичног курса теоријског карактера, практикума са задацима и два компакт-диска са видео-прилозима. Тематски опус које ауторка нуди чини једанаест актуелних методичких области. У питању су: базични појмови и категорије методике руског језика као страног, психолингвистичке основе овладавања страним језиком, настава руског изговора, настава граматике руског језика, настава лексике руског језика, настава говорења, настава аудирања, настава читања, настава писања, организација контроле и самосталног рада, као и настава руске културе на часовима руског језика као страног. Како је на већини домаћих и страних универзитета настава методике најчешће конципирана по принципу извођења предавања и вежби, тако је и овај уџбенички комплет еквивалентно замишљен да пружи теоријски и практични план садржаја дате области. 
Практични курс представља сегмент који кориснику комплета треба да помогне у теоријским сагледавањима методике наставе руског језика као страног, упути га у категоријално-базичне појмове њеног терминосистема, као и у теоријске аспекте поменутих једанаест тема. Након сваког поглавља налази се прегледни попис коришћене литературе са пуним библиографским описом који кориснику овог комплета може да послужи за даља истраживања и самостално продубљивање знања из области методике наставе. На крају овог сегмента налазе се и три додатка: примери комплексне анализе плана часа, решења најтежих задатака, као и образац дневника методичке праксе што посебно може бити драгоцено при практичном оспособљавању студената на универзитету у оквиру методичке праксе и приликом самосталног усавршавања.

Изузетно важан и, могуће, најкориснији сегмент датог комплета јесте практикум са задацима. Наиме, након упознавања са конкретном теоријском целином у делу практичног курса, ауторка у практикуму нуди за свако поглавље читав комплекс садржаја који одређену материју сагледава из великог броја перспектива. На плану микроструктуре сваког од једанаест поглавља то се манифестује кроз различите задатке и понуђене садржаје, одговарајући део плана часа, контролна питања и списак препоручене литературе усмерене ка датој теми. Заступљени су разноврсни задаци отвореног и затвореног типа који потенцијалном кориснику датог комплета нуде да различите лингводидактичке термине сам формулише или конкретизује (нпр. функционално-комуникативни приступ, фрејм, системско-структурни пристуn, умење), наведе позитивне и негативне стране конкретних појмова, затим да објасни суштинске разлике у значењски сродним терминима (нпр. лингводидактика наспрам методике, језичка компетенција наспрам лингвистичке компетенције, граматичке структуре наспрам граматичких модела итд.), сагледа проблематику усвајања страног језика, чак и у односу на матерњи (питања Л1, Л2 и Л3) из перспективе психологије. Даље, кроз садржаје практикума даје се могућност аргументације сопственог става по питању конкретних методичких ситуација и поступака у различитим фазама часа (нпр. препаративној и оперативној), стицања увида у постојање великог броја вежбања и начина контроле ученика, организовање наставног процеса, разматрања структуре различитих типова часа (обрада новог материјала, утврђивање, комбиновани тип часа итд.), у зависности од понуђених једанаест области, затим самосталног вршења одабира потребног језичког и дидактичког материјала, могућности увида у припреме за час и у извесној мери стављање у улогу наставника. 
Ништа мање битна нису ни два компакт-диска на којима се налазе конкретни примери реализације часа који се тичу како језичких нивоа (нпр. фонетике, морфологије, лексике) тако и видова говорне делатности (рецептивних и продуктивних). Они служе за анализу и у директној су спрези са практикумом. Њихова анализа може бити од великог значаја будући да се на примеру датих часова могу разматрати предности и мане одређених наставних метода и поступака, добити идеје за примену нових, развити перцептивне способности и способност иницијативе и преузимања одговорности за своје одлуке и проналажење адекватног решења, чак и у непланским ситуацијама часа. Они могу дати очигледане примере саме артикулације часа, начина обраде, систематизације, утврђивања и контроле усавајања одређеног материјала, уз извесну дозу адаптације чак и на српској говорној средини.

Оно што дати новитет издваја јесте његова изражена практична усмереност на усвајање различитих методичких знања и уједно развијање методичких компетенција попут владања комуникативним стратегијама и тактикама, умењима адекватног коришћења поступака приликом решавања професионалних задатака, припреме различитог типа материјала, владање навикама организације и одржавања наставе, владање навикама држања наставе у разним образовним профилима и многим другим.

Теоријски аспект сагледавања несумњиво је од изузетног значаја за сваку науку, па тако и методику наставе, међутим уџбенички комплет Нине Федотове представља један од малобројних извора у савременој русистичкој методичкој продукцији који има овакав тип усмерености, који нуди савлађивање, утврђивање и проверу методичког градива на дати начин. Он може наћи импликацију у настави многих предмета методичке оријентације и током реализације методичке праксе студената русистике, где би, како и сама ауторка наводи, овај користан методички извор нашао своју адекватну примену.

\section{Срђан Р. Петровић}

Филолошки факултет, Катедра за славистику Београд - мастерант srdjan09@mail.ru 